ROMAN NIR

\title{
THE FIRST POLISH AMERICAN BRIGADIER GENERAL REV. MSGR. THADDEUS F. MALANOWSKI 1922-2020
}

Thaddeus Malanowski was born in 1922 in Stamford, Connecticut, as the son of Polish immigrants who came to America at the turn of the century. He attended Holy Name of Jesus Elementary and Junior High Thomas Seminary in Hartford, CT in 1937, where he completed two years of college. In 1942 he began his philosophy at St. Bernard Seminary in Rochester, NY, from which he graduated with a B.A. in 1944. After completion of 4 years of Theology at St. Bernard Seminary, Chaplain Malanowski was ordained into the priesthood at St. Joseph's Cathedral on May 15, 1947 by Bishop Henry J. O’Brien.

He served at two parishes in Connecticut before he was commissioned as a First Lieutenant in the Army Chaplaincy with the $118^{\text {th }}$ Medical battalion, 43rd Infantry Division, in Hartford, Connecticut on December 29, 1949. Nine, months later Chaplain Malanowski left the civilian ministry and entered active duty as chaplain with the 43rd Infantry Division at Camp Pickett, Virginia, where he joined the $172^{\text {nd }}$ Infantry Regiment.

In 1951 he went overseas as part of the NATO forces in Europe. From October 1954 until July 1955, he served as Assistant Post Chaplain at Fort Benning in Georgia. He was later assigned to the $3^{\text {rd }}$ Armored Division at Fort Knox, Kentucky, from which he departed for Europe in 1956 accompanying Combat Command "C".

In 1960, Chaplain Malanowski was assigned to Carlisle Barracks, PA, the home of the U.S. Army War College, where he served as Assistant Post Chaplain. He graduated from the Command and General Staff College at Fort Leavenworth, Kansas, in May 1962. In 1964, he departed for Korea where he served with the Eighth Army Support Command. Upon completion of his tour in Korea in July 1965, he joined the Fifth Army Headquarters in Chicago, Illinois, where he held the post of Administrative Chaplain. The following year he became the Deputy Chaplain of the Fifth U.S. Army.

Fr. Dr. Roman NIR - Institute of History and Polonia Archives. Former Director of the Central Polonia Archives at Orchard Lake, USA. Historian and Polonia Archivist. Ordinary member of the PTNO; e-mail: romannir@gmail.com 
In 1967, Chaplain Malanowski was assigned overseas to Headquarters, U.S. Army Europe and Seventh Army as Assistant Chief of the Religious Plans and Programs Division, a post he held for 33 months. His last 12 months there were spent as Chaplain Delegate to Terence Cardinal Cooke for Germany, Belgium and Holland. Upon completion of his tour in Heidelberg in June 1970, he was assigned as Command Chaplain ARADCOM, Ent. Air Force Base, Colorado, having been promoted to the rank of Colonel in April 1970.

In 1973, Chaplain Malanowski returned to USAREUR and the Seventh Army Headquarters as Deputy Chaplain and Delegate to Cardinal Cooke. In 1974, he was nominated by President Richard Nixon to be the new Deputy Chief of Army Chaplains with the rank of Brigadier General. On February 8, 1974, his nomination was approved by the Senate. His promotion ceremonies took place in Heidelberg, Germany, on February 11 and were conducted by General Michael S. Davison, Commander-in-Chief, U.S. Army Europe and Seventh Army.

During his career in the U.S. Army, Chaplain Malanowski received military decorations and awards, including the Distinguished Services Medal, the Legion of Merit, the Meritorious Service Medal, Army Commendation Medal with 2 Oak Leaf Clusters, National Defense Medal with Oak Leaf Cluster, and the World War II Occupation Medal. He has also received several civilian awards, including: Four Chaplains Award, presented by Chaplain Alexander D. Goode - Ben Goldman Lodge of B'Nai B'rith in March of 1971 for outstanding interfaith activities; Papal Award - Prelate of Honor with the title of Monsignor, appointed by Pope Paul VI in December 1973.

In May 1982, Brigadier General Malanowski received his Master of Divinity degree from St. Bernard Institute - Colgate Theological University in Rochester, New York. He retired from the U.S. Army in March of 1978, after completing over 28 years of service. He studied in Rome, Italy in 1978 and was assigned as Pastor of St. Andrew's Church in Colchester, Connecticut from 1981 to 1984, and a missionary in Haiti from 1981 to 1992 . Currently Chaplain Malanowski resides and performs pastoral work in the Diocese of St. Petersburg, Florida. He is a member of the Board of Directors of the Polish American Priests Association and he is active in Polish American affairs.

Monsignor Malanowski was a great friend of Orchard Lake Schools. The Archives of the Polish Seminary offered their documents, correspondence, decorations and uniforms. He was awarded the "Fidelitas Medal" by schools in 2003. Monsignor is the author of the book "Sacrifice For GOD and Country" 2012. Monsignor Ted's encounters with many great figures of the $20^{\text {th }}$ century including Pope Pius XII, John Paul II, Teresa Neumann, Cardinal Francis Spellman, Cardinal Terrence Cooke, Stefan Cardinal Wyszyński, four American Presidents, General Creighton Abrams, Chancellor Conrad Adenauer of Germany, and Elvis Presley.

Msgr. Thaddeus F. Malanowski died January 23, 2020, Stamford, Connecticut. He was buried in St. John's Catholic Cemetery in Darien Ct. 